\title{
1.リアルワールドデータの医薬品等の承認審查，製造販売後 安全性監視に関する薬事制度下での利活用の進展
}

\author{
小居 秀紀*1, 中村 治雅*2 \\ ${ }^{* 1}$ 国立研究開発法人国立精神・神経医療研究センタートランスレーショナル. \\ メディカルセンター 臨床研究支援部 開発戦略室 \\ *2 国立研究開発法人国立精神・神経医療研究センタートランスレーショナル. \\ メディカルセンター 臨床研究支援部 臨床研究支援室
}

く抄録>リアルワールドデータを取り巻く薬事規制の環境は，医薬品等開発，製造販売後 のいずれのフェーズに拈いても，今まさに，大きな変革を迎えている.

まず，医薬品開発に関しては，ICHにおけるE8 ガイドライン（臨床試験の一般指針）の 近代化と引き続き行われる E6 ガイドライン (ICH-GCP) の改訂である「GCP Renovation」 がある。ここでは実際的臨床試験（Pragmatic Clinical Trial）や患者レジストリデータを 用いたランダム化比較試験，さらにリアルワールドデータを全部または一部用いる非介入 の観察研究までも対象範囲となっている。この動きは，米国における「21st Century Act (21 世紀治療法)」に抢いて, 臨床試験の合理化等による薬事承認迅速化の課題として取り 上げられ, 適応拡大の承認審査の際にリアルワールドデータが用いられる事例も出ている. また，日本に扔いても，クリニカル・イノベーション・ネットワーク構想のもと，患者レ ジストリ等の自然歴研究データを治験対照群として承認審査資料に用いることの検討が進 んでいる.

次に，製造販売後に関しては，「医薬品の条件付き早期承認制度について（平成 29 年 10 月 20 日, 薬生薬審発 1020 第 1 号) 」に扔いて, 条件解除の要件として, 医療情報データベー ス (MID-NET) 事業やクリニカル・イノベーション・ネットワーク構想に扔ける患者レジ ストリのようなリアルワールドデータを用いた製造販売後の有効性・安全性の確認が記述 された。また,「医薬品の製造販売後の調査及び試験の実施の基準に関する省令 (いわゆる GPSP 省令) (平成 29 年 10 月 26 日, 厚生労働省令第 116 号)」において, MID-NET 等の 医療情報データベースを用いて実施する調査である「製造販売後データベース調査」が新 たに規定され，製造販売後の安全性監視活動に扔けるリアルワールドデータの利活用が開 始されたところである。

(薬剤疫学 $2019 ； 24(1): 2-10)$ キーワード：リアルワールドデータ（RWD）, GCP Renovation, 患者レジストリ，クリニ カル・イノベーション・ネットワーク (CIN), 条件付き早期承認制度

\section{1.はじめに}

リアルワールドデータを取り巻く薬事規制の環 境は, 医薬品等開発, 製造販売後のいずれのフェー
ズにおいても，今まさに，大きな変革を迎えてい る.

まず，医薬品開発に関しては，医薬品規制調和

著者連絡先： $\bar{\top}$ 187-8551 東京都小平市小川東町 4-1-1 国立研究開発法人国立精神・神経医療研究センター トランスレーショナル・メディカルセンター臨床研究支援部開発戦略室 小居秀紀

TEL : 042-341-2712（ダイヤルイン）3125（PHS） FAX : 042-346-3503 E-mail : oih@ncnp.go.jp 
国際会議（ICH）における E8 ガイドラインの近代 化と引き続き行われる $\mathrm{E} 6$ ガイドラインの改訂で ある「GCP Renovation」がある。ここでは Pragmatic Clinical Trial や患者レジストリデータを用 いたランダム化比較試験, さらにリアルワールド デー夕を全部または一部用いる非介入の観察研究 までも対象範囲となっている。この動きは，米国 における「21st Century Act」光において，臨床試 験の合理化等による薬事承認迅速化の課題として 取り上げられ, 適応拡大の承認審査の際にリアル ワールドデータが用いられる事例も出ている。 ま た, 日本に抏てても, クリニカル・イノベーショ ン・ネットワーク構想 ${ }^{3)}$ のと, 患者レジストリ 等の自然歴研究データを治験対照群として承認審 查資料に用いることの検討が進んでいる.

次に, 製造販売後に関しては,「医薬品の条件付 き早期承認制度について（平成 29 年 10 月 20 日, 薬生薬審発 1020 第 1 号) 」4)において, 条件解除の 要件として, 医療情報データベース（MID-NET） 事業 ${ }^{5)}$ や患者レジストリのようなリアルワールド データを用いた製造販売後の有効性・安全性の確 認が記述された。また，「医薬品の製造販売後の 調査及び試験の実施の基準に関する省令 (平成 29 年 10 月 26 日, 厚生労働省令第 116 号) 」吕におい て，MID-NET 等の医療情報データベースを用い て実施する調査である「製造販売後データベース 調査」が新たに規定され, 製造販売後の安全性監 視活動におけるリアルワールドデータの利活用が 開始されたところである.

本稿では, リアルワールドデータの医薬品等の 承認審査や製造販売後の安全性監視に関する薬事 制度下での利活用の現状, 課題, そして今後の方 向性について報告したい.

\section{2.「GCP Renovation」の概要}

2016 年 11 月に大阪で開催された第 3 回 ICH において, FDA より“GCP Renovation”（GCP 刷 新-ICH E8 の近代化と引き続き行われる ICH E6 の改訂）の提案がなされた. また, 2017 年 1 月 12 日には ICH 本部より “GCP Renovation”に関す る Reflection paper が発出され, 同年 3 月 11 日
まで Public consultation が行われた.さらに, 米 国では 2016 年 12 月 13 日に「21st Century Cures Act」が成立したが, その中で臨床試験の合理化 等による薬事承認迅速化の一つとしてリアルワー ルドデータの利活用が取り上げられている.

ICH の Reflection paper で提案されている “GCP Renovation” の概要と E6 ガイドラインの 構成を表 1 にまとめた. 改訂後の E6 ガイドライ ンの構成は, あらゆる臨床研究に共通する原理原 則を記述する Overarching Principles と, 臨床研 究のタイプに応じて分けられた 3 つの別添 (Annex）からの 4 部構成となっている. Pragmatic Clinical Trials のような試験デザインは「Annex 2」に含まれており，一般化可能性を高めるための 臨床試験や, 電子化されたデータソースを利用す る際の留意点等が述べられる。また,「Annex 3」 では, Annex 1，2 に含まれない非介入の観察研 究を含むあらゆる臨床研究デザイン, リアルワー ルドデータを全部または一部に用いる臨床研究が 含まれる，従来の主な適用範囲だった介入を伴う 臨床試験のみならず，一般的な観察研究や患者レ ジストリ等のリアルワールドデータを用いた臨床 研究の一部も, E6 ガイドライン (ICH-GCP) の対 象範囲となることになる

“GCP Renovation”は, 一義的には ICH-GCP の非介入研究を含めた対象範囲の拡大であるた め, 特にアカデミアが主体となって実施する研究 者主導臨床研究や患者レジストリの構築等へのイ ンパクトが大きいと考えるが, 決してマイナス面 だけではない. ICH-GCP の要求事項の強化ばか りではなく, 状況に応じて要求事項が整理され弱 められる部分もあり, 日本における臨床研究の課 題である薬事規制のダブルスタンダードの意義が 薄れる面での貢献も期待される.

\section{3.「クリニカル・イノベーション・ネットワーク」 構想の推進}

クリニカル・イノベーション・ネットワーク (Clinical Innovation Network : 以下, CIN (図 1)) とは, 疾患登録システム（患者レジストリ）等の 各種疾患登録情報を活用して, 関係機関が連携し 
4 企画／リアルワールドデータ活用による承認審査・安全性監視の進展・チャレンジ

表 1 提案されている“GCP Renovation”の概要と E6 ガイドラインの構成

\section{ICH Reflection paperで提案されている“GCP Renovation” の概要}

1) Quality By Design(計画に基づいた質の確保)が目標に据えられ、提案されている E8(臨床試験の 一般指針)、E6(臨床試験の実施の基準)にはこの考え方が色濃く反映されること

2) 製造販売承認前(あるいは直後)の段階の臨床試験のみならず、製造販売後のエビデンス創出に つながる臨床研究もScope に入ること

\begin{tabular}{|c|c|}
\hline \multicolumn{2}{|c|}{ ICH Reflection paperで提案されているE6ガイドラインの構成 } \\
\hline Overarching Principles & $\begin{array}{l}\text { あらゆる臨床試験, 臨床研究において考慮されるべき原則 } \\
\text { (被験者の保護, 質の確保） }\end{array}$ \\
\hline $\begin{array}{l}\text { Annex 1: } \\
\text { Traditional Interventional Trials } \\
\text { of Investigational Unapproved or } \\
\text { Approved Drugs }\end{array}$ & $\begin{array}{l}\text { 従来のGCPの主な適用範囲だった介入を伴う臨床試験. } \\
\text { E6ガイドライン(R2)の更なる改訂を含む. }\end{array}$ \\
\hline $\begin{array}{l}\text { Annex 2: } \\
\text { Non-traditional Interventional } \\
\text { and/or Data Source }\end{array}$ & $\begin{array}{l}\text { Annex } 1 \text { に含まれない介入を伴う臨床試験と, 電子化されたデータ } \\
\text { ソ一ス. } \\
\text { 実際的臨床試験(Pragmatic Clinical Trials), 患者レジストリを用いた } \\
\text { ランダム化臨床試験などの一般化可能性を高めるための臨床試験 } \\
\text { や, 電子化されたデータソースを利用する際の留意点など. }\end{array}$ \\
\hline $\begin{array}{l}\text { Annex 3: } \\
\text { Non-traditional Trial Designs }\end{array}$ & $\begin{array}{l}\text { Annex 1, } 2 \text { に含まれない非介入の観察研究を含むあらゆる臨床研 } \\
\text { 究デザイン, Real World Dataを全部又は一部に用いる臨床研究も } \\
\text { 含まれる. }\end{array}$ \\
\hline
\end{tabular}

て効率的な治験・臨床研究を実施できる臨床開発 の環境を整備することである。 2020 ジャパン・ チャレンジ・プロジェクトの一つとして取り上げ られたことを皮切りに，「日本再興戦略改訂 2015 および 2016」さらに「未来投資戦略 2017 および 2018」でも, 具体的施策として取り上げられた。 世界的にも, 新しい医薬品, 医療機器等の開発, 製造販売後の安全性監視において, 患者レジスト リを活用した新たな臨床開発, 安全性評価等の手 法が注目されている。このような背景のもと，特 に患者レジストリを治験・臨床研究に対して最大 限活用するため, 関係機関のネットワークを構築 し, 産学連携による治験コンソーシアムを形成す るとともに，患者レジストリ情報を活用した臨床 評価の手法に関するレギュラトリーサイエンス研 究を行うことが求められている.

具体的な活動については, 2016 年度より, 国立 研究開発法人日本医療研究開発機構（Japan Agency for Medical Research and Development, 以下, AMED）によるいくつかの研究班で検討が 進められている。特に, 医薬品等規制調和・評価 研究事業「患者レジストリデータを活用した臨床
開発効率化のための新たな臨床研究デザインの開 発（研究開発代表者：群馬大学・林邦彦氏)」の研 究班において, 患者レジストリを活用した臨床開 発の促進と効率化のために, 規制要件, 規制科学 の観点から検討が行われている。希少疾患や医療 機器, 再生医療等製品等の一般的な臨床試験の実 施が困難である領域での患者レジストリ利活用に よる開発を進めるための臨床研究デザインと解析 法を検討すること，患者レジストリ利活用による 規制当局の意思決定を行う際に求められるレジス トリ保有者に対する信頼性基準の考え方の検討, の大きく二つの課題に取り組んでいる. 平成 29 年度には, 当研究班により「患者レジストリデー 夕を医薬品等の承認申請資料等として活用する場 合におけるデータの信頼性担保に関する基本的考 え方(案)」が作成されており, 患者レジストリデー 夕を医薬品等の臨床開発, 製造販売後調査等に利 活用する際の信頼性担保に関する考え方が示され ている.なお, この提言は, 平成 30 年 2 月 21 日 に発出された「医薬品の製造販売後データベース 調查における信頼性担保に関する留意点につい て」8)も踏まえているが, 患者レジストリデータの 


\section{クリニカル・イノ゙ーション・ネットワークの構築 \\ （疾患登録情報を活用した臨床開発インフラの整備）}

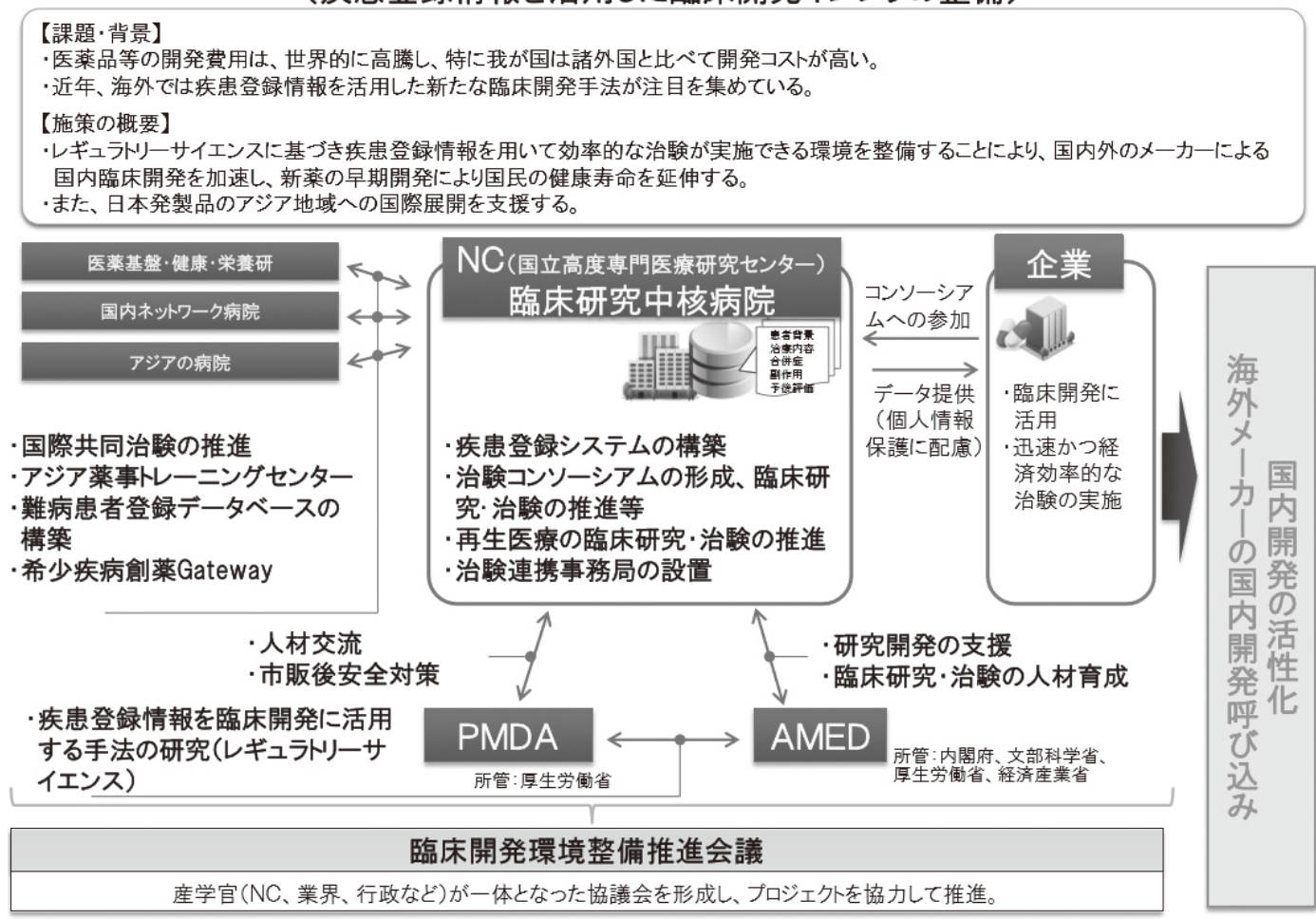

図 1 クリニカル・イノベーション・ネットワーク

治験対照群等の承認審査資料としての利活用にも 踏み込んだ内容となっている。

なお, 国立精神・神経医療研究センター $(\mathrm{Na}-$ tional Center of Neurology and Psychiatry，以下， NCNP）では，AMED・患者レジストリ構築事業 として採択された「難病, 希少疾患の医薬品開発 におけるCIN 構想の推進を目指した疾患登録シ ステム（患者レジストリ）の構築（研究開発代表 者：NCNP・中村治雅)」により再構築を行ってい る，筋ジストロフィーを中心とした神経筋疾患の 患者レジストリである Remudy（Registry of Muscular Dystrophy）や, 治験や臨床研究に資す るデータ収集を目的とした精神疾患レジストリで ある RoMCo (Registry of Mental Condition) ${ }^{9}$ 等 の活動を通じ, CIN の具現化を進めている. ま た, 治験対照群に資するデータ収集を目的とした 「歩行可能なデュシェンヌ型筋ジストロフィーの
自然歴研究（UMIN 試験 ID：UMIN000030562）」 を，筋ジストロフィー臨床試験ネットワーク (Muscular Dystrophy Clinical Trial Network: MDCTN）加盟施設との多施設共同研究として実 施している。当該臨床研究では, 主要アウトカム 評価項目となる運動機能評価において, 現時点で 治験における有効性評価指標のグローバル標準と 言われている「6 分間歩行試験」のデータを収集 しており，また，医師主導治験で実績のある EDC (Electronic Data Capture) の使用及び全参加機 関での原資料と症例報告書の照合による確認 (Source Document Verification あるいはSource Date Verification：SDV）を含むモニタリングの 実施等の臨床データの信頼性確保のための方策も 行っている. 
6 企画 /リアルワールドデータ活用による承認審査・安全性監視の進展・チャレンジ

\section{4 、「医薬品の条件付き早期承認制度」を見据え た取組み}

平成 29 年 10 月 20 日に「医薬品の条件付き早 期承認制度の実施について」が発出された。重篤 な疾患であって有効な治療方法がそしく患者数が 少ない疾患等を対象とする医薬品については, 日 本での治験実施が困難，あるいは実施可能であっ ても治験の実施にかなりの長期間を要する場合に は, これまでも状況に応じて個別に検討し，検証 的臨床試験の成績が求められることなく, 製造販 売後に必要な調査等を実施することを承認条件と して当該医薬品の製造販売承認が行われてきた. 本通知の発出により, これまでの取り扱いが整理 され明確となったことで, 企業では開発予見性が 高まり, 早期の実用化につながるものと期待され る.

本制度の対象品目の要件は, 以下の (1) (4)の いずれにも該当する医薬品となる.

(1) 以下に分類して総合的に評価した結果, 適応 疾患が重篤であると認められること

1 ）生命に重大な影響がある疾患（致死的な 疾患）であること

2 ) 病気の進行が不可逆的で, 日常生活に著 しい影響を及ぼす疾患であること

3 ）その他

(2) 以下に分類して総合的に評価した結果, 医療 上の有用性が高いと認められること

1 ）既存の治療法, 予防法又は診断法がない こと

2 ) 有効性, 安全性, 肉体的・精神的な患者 負担の観点から, 医療上の有用性が既存 の治療法, 予防法又は診断法より優れて いること

(3) 検証的臨床試験の実施が困難であるか, 実施 可能であっても患者数が少ないこと等によ り実施に相当の期間を要すると判断される こと

(4) 検証的臨床試験以外の臨床試験等の成績に より, 一定の有効性, 安全性が示されると判 断されること

このうち (1) と (2) は, 現行の優先審査の適用要件
を満たすことになるため, 優先審査の対象になる.

本制度の重要なポイントは二つで, 承認審査資 料となる臨床試験の内容（試験デザイン, 試験結 果, デー夕の信頼性等) と, 条件解除の要件であ る. 特に条件解除の要件では, 製造販売後に安全 性のみならず, 有効性を再確認するための調査等 の実施が明記されており，医療情報データベース （MID-NET）事業や CIN 構想における患者レジ ストリのような, リアルワールドデータの利活用 が期待される.

\section{5 ㄷAMED・リアルワールドデータの薬事制度 下での利活用に関する研究班」の取組み}

平成 29 年 10 月 26 日には「医薬品の製造販売 後の調査及び試験の実施の基準に関する省令等の 一部を改正する省令」が交付 (平成 30 年 4 月 1 日 施行）され，平成 30 年には 4 月 1 日に「医療情報 データベース基盤整備事業 (MID-NET)」の本格 運用が開始された. また, 平成 29 年 5 月 12 日に 交付されたいわゆる「次世代医療基盤法 $\rfloor^{10)}$ が平 成 30 年 5 月 11 日に施行となった。 これらのよう にリアルワールドデータの製造販売後の安全性監 視に向けた環境整備が進んでいる.

これらを受け，2018 年（平成 30 年）4 月より， AMED 医薬品等規制調和・評価研究事業「リアル ワールドデータ等の新たなデータソースの規制上 の利用等とその国際規制調和に向けた課題の調 査・整理等に関する研究（研究開発代表者： $\mathrm{NCNP}$ ・ 中村治雅)」の活動を開始している. 本研 究は, CIN 事業を中心的に推進してきた NCNP と MID-NET 事業の研究者, 生物統計学やデー 夕管理学の研究者等を研究開発分担者とし, 厚生 労働省, AMED, 医薬品医療機器総合機構 (PMDA), ならびに日本薬剤疫学会や日本製薬医 学会等の関係学会及び日本製薬工業協会等の関連 団体との緊密な連携, 情報共有のもとに，(1) 疾 患登録システム (患者レジストリ)や医療情報デー タベース等のリアルワールドデータの薬事制度下 における安全性情報の利活用及び副作用情報収集 の基準に関する諸外国や国際会議等の海外事例の 検討状況を調査し, その結果を踏まえた課題整理 
を行うこと，(2）GCP Renovation（ICH E6 及び E8 ガイドラン改訂) 後の研究者主導臨床研究に おける国内導入に向けた調査や課題整理を行うこ と，（3）適切なアウトカムメジャーの設定等の有 効性評価での利活用に関する調查や課題整理を行 うこと，を目的としている。

本研究を開始するにあたり, 現状の製造販売後 の安全性監視や, GCP Renovation 後の国内導入 における課題を整理した。まず，「“真の安全性情 報”を患者や国民に提供する」という視点である． 製造販売承認前の治験では副作用発現率が $80 \%$ を超えていたものが, 製造販売後には $10 \%$ 未満と して医師等の医療者に提供されることがある。医 師は当該医薬品の実臨床での使用経験から副作用 発現率をしっかり認識しており，真の副作用発現 率は両者の間であることがほとんどであろう（図 2)，真の安全性情報を収集できる仕組みが必要と 考える。

次に,「リアルワールドデータはデータソース によって情報・データの質や個人情報保護のス キームが異なる」ことの理解である。平成 29 年 6 月 9 日に「製造販売後の医薬品安全性監視におけ る医療情報データベースの利用に関する基本的考 え方について (平成 29 年 6 月 9 日, 薬生薬審発 0609 第 8 号・薬生安発 0609 第 4 号) 」 ${ }^{11}$ が発出さ れ, 本通知における「医療情報データベース」と

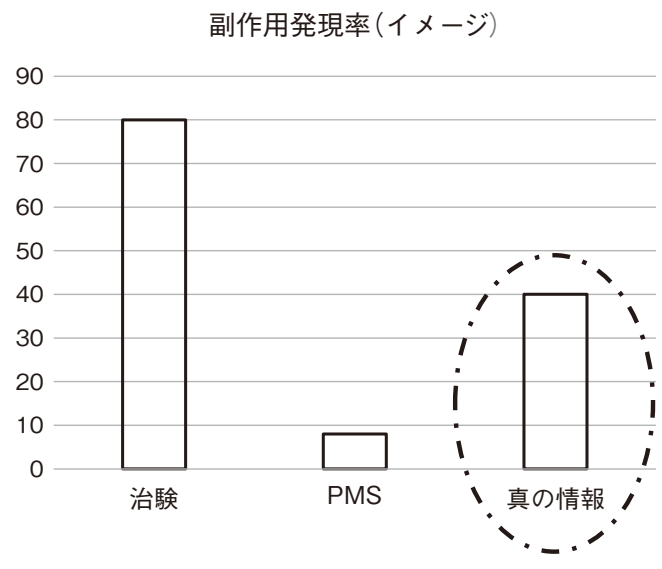

図 2 “真の安全性情報”の提供

は, 病院情報システムデータ（電子カルテデータ， 診断群分類包括評価 (DPC) デー夕等), 診療報酬 ならびに調剂報酬明細書（健康保険組合レセプト デー夕等）及び疾患登録デー夕等の電子的な医療 情報を体系的に集積したデータベースを指すも の，と定義された．これらさまざまな医療情報が “リアルワールドデータ”と同じ用語で使用され ているものの, データソースによって, 情報・デー 夕の質及び信頼性確保や, 個人情報保護への配慮 のスキームは異なるため, 製造販売後の安全性監 視に資するデー夕収集, 利活用の基準設定が必要 と考える（図 3)。なお，レギュラトリーサイエン

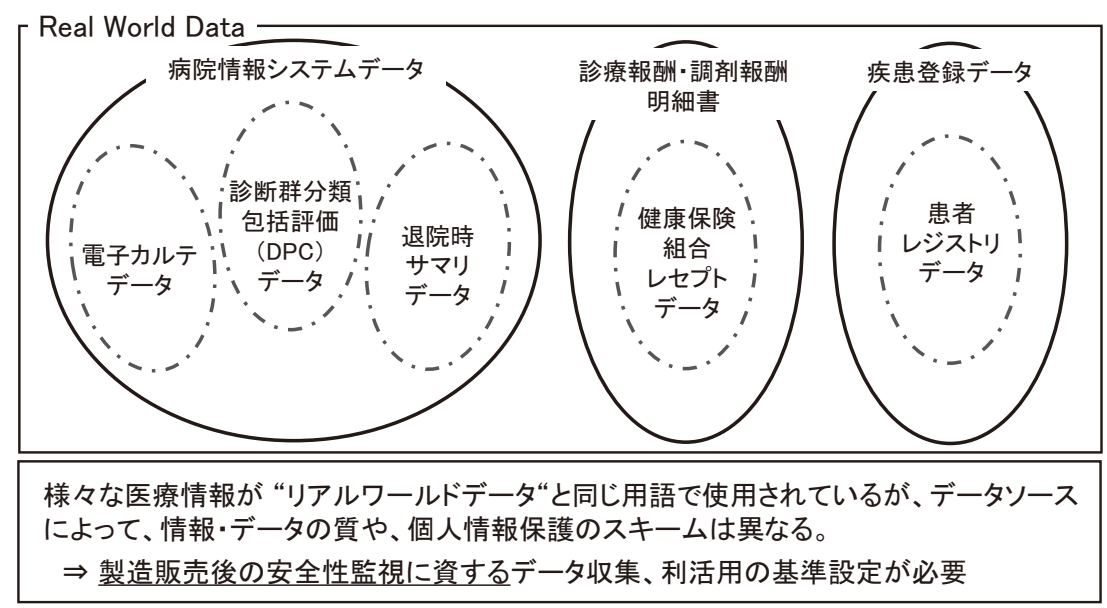

図 3 医療情報データベースを利用した医薬品安全性監視活動 


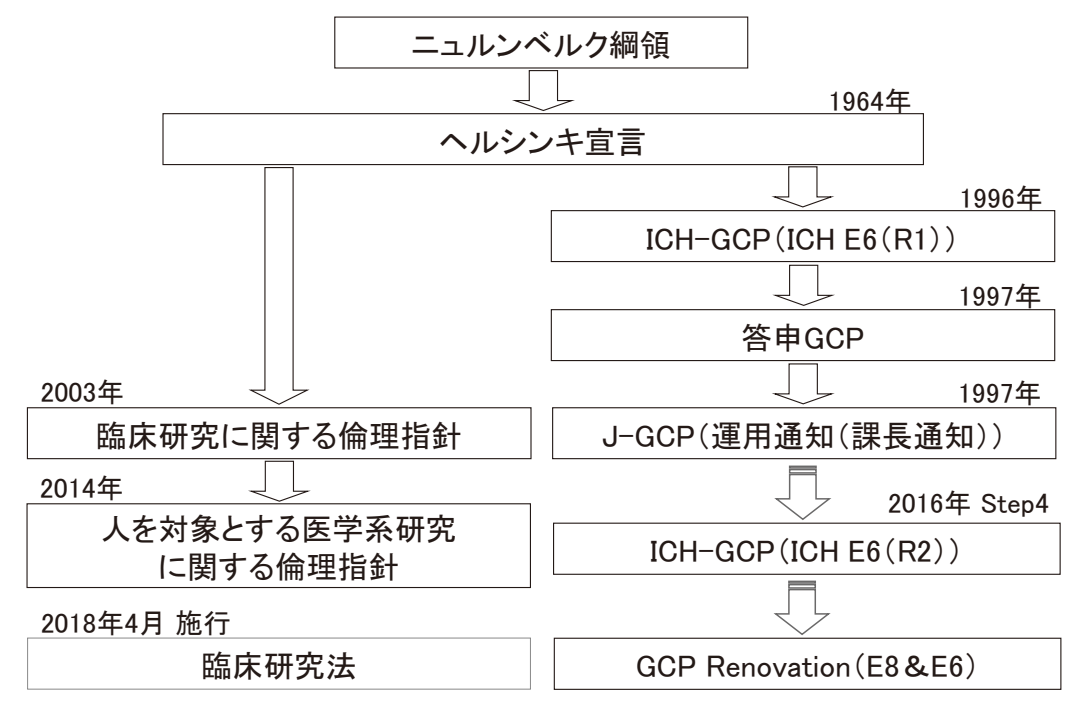

図 4 ICH E6 ガイドライン (ICH-GCP), 倫理指針, 臨床研究法制定のフロー

スの関連性から, 情報・データの質及び信頼性確 保には 3 つの段階があり，（1）臨床情報の提供元 となる医療機関等からデータベース保有者への データ収集・移行, (2) データマネジメントやコー ディングを含むデータベース保有者内のデータ保 管・管理，データセット提供，（3）データベース 保有者からの提供されたデータセットに基づく集 計・解析結果，報告書作成，であるが，それぞれ の段階におけるデータの質管理, 信頼性確保の方 策が求められる.

最後は, 「日本における研究倫理, ICH-GCP に 係る薬事規制におけるグローバル標準との相違 点, ダブルスタンダードを克服する」ことである. ニュルンベルク綱領・ヘルシンキ宣言以降の ICH-GCP の国内導入のフロー，人を対象とする 医学系研究に関する倫理指針, そして, 平成 30 年 4 月 1 日に施行となった臨床研究法の制定フロー を示す (図 4). 原則として介入研究が対象となる 臨床研究法の施行は, 実質的に介入研究の場合に は，その実施において ICH-GCP を踏まえること となると思われるが, Pragmatic Clinical Trials や非介入研究である患者レジストリの場合には, GCP Renovationの国内導入において特別の配慮 が必要と考える.
今後, 本研究では, それぞれの分担研究班にお いては, 電子的医療情報からのデー夕取得や CDISC (Clinical Data Interchange Standards Consortium）標準等のリアルワールドデータの登 録・収集面, データベースの保守・管理やデータ クリーニング・コード化等のデータ管理学的課題 面, 疫学研究における統計解析手法を含む統計学 的課題面から調査, 課題整理や, GCP Renovation ( ICH E6 及び E8 ガイドラン改訂) 後の研究 者主導臨床研究における国内導入に向けた調査や 課題整理等を行うが, 関係者のご支援, ご協力を, 是非ともお願いしたい.

\section{6. おわりに}

本稿では, リアルワールドデータの医薬品等の 承認審査や製造販売後の安全性監視に関する薬事 制度下での利活用の現状, 課題, 現在検討されて いる研究そして今後の方向性について述べた。

“リアルワールドデータ”の質及び信頼性確保及 び個人情報保護への配慮には，そのデータソース に関わる多くの医師等の医療関係者や, 研究者主 導臨床研究における研究代表者, 研究責任者・分 担者・協力者, さらにデー夕の発生源である医療 機関, ならびに患者やその家族の高い意識, 理解 
薬剂疫学 Jpn J Pharmacoepidemiol, 24(1) Jan 2019:9

が必須である。今後, “リアルワールドデータ”の 薬事制度下での利活用に係る環境変化に対応する ため, 日本全体としての取組み, 仕組み作りが期 待される.

日本で実施される治験の強みは, 評価基準の統 一性, 選択・除外基準違反の少なさ, 被験者の規 則正しい来院，フォローアップの確実性，データ の正確性等の「質」の高さである。これらは, “リ アルワールドデータ”の生成プロセスとなる研究 者主導臨床研究や疾患登録システム（患者レジス トリ）の構築, 運営・管理においても同様であり, その強みを活かした“リアルワールドデータ”生 成の仕組み作りが, 日本における医薬品等の新規 医療技術の実用化, 製造販売後の適切な安全性監 視に貢献するものと期待する.

\section{文献}

1) The International Council for Harmonisation of Technical Requirements for Pharmaceuticals for Human Use (ICH). ICH Reflection on "GCP Renovation” : Modernization of ICH E8 and Subsequent Renovation of ICH E6. January 2017. [https://www. ich.org/products/gcp-renovation.html (accessed 2017-12-1) ]

2) U.S. Food and Drug Administration. 21st Century Cures Act. [https://www.fda.gov/regulatoryinfor mation/lawsenforcedbyfda/significantamendment stothefdcact/21stcenturycuresact/default.htm (accessed 2017-12-1) ]
3) 中村治雅, 武田伸一. クリニカル・イノベーション・ ネットワーク。整形・災害外科 2018 ；61（4）：41924.

4）厚生労働省. 医薬品の条件付き早期承認制度の実施 について. 厚生労働省医薬・生活衛生局医薬品審査 管理課長. 薬生薬審発 1020 第 1 号 平成 29 年 10 月 20 日。

5) 独立行政法人医薬品医療機器総合機構. MID-NET (Medical Information Database Network). [https://www.pmda.go.jp/safety/mid-net/0001. html (accessed 2017-12-1) ]

6) 厚生労働省. 医薬品の製造販売後の調査及び試験の 実施の基準に関する省令等の一部を改正する省令の 公布について。厚生労働省医薬・生活局長. 平成 29 年厚生労働省令第 116 号. 平成 29 年 10 月 26 日公 布・平成 30 年 4 月 1 日施行.

7）小宮山靖. GCP 刷新（GCP Renovation）のインパ クト。医薬品医療機器レギュラトリーサイエンス 2017 ; 48 (5) : 278-81.

8）厚生労働省. 医薬品の製造販売後データベース調査 における信頼性担保に関する留意点について，厚生 労働省医薬 ·生活衛生局医薬品審査管理課長. 薬生 薬審発 0221 第 1 号 平成 30 年 2 月 21 日.

9）吉村直記, 小居秀紀, 山之内芳雄, 永井秀明. IT を 使った患者レジストリーシステム。精神科 $2017 ; 30$ (5) : 448-54.

10）医療分野の研究開発に資するための匿名加工医療情 報に関する法律施行令. 平成 30 年政令第 163 号. 平成 30 年 5 月 7 日公布. 平成 30 年 5 月 11 日施行.

11）厚生労働省. 製造販売後の医薬品安全性監視におけ る医療情報データベースの利用に関する基本的考え 方について，厚生労働省医薬・生活衛生局医薬品審 查管理課長, 厚生労働省医薬 - 生活衛生局安全対策 課長. 薬生薬審発 0609 第 8 号 薬生安発 0609 第 4 号平成 29 年 6 月 9 日. 
Special Issue on "Progress and Challenge of Drug Development and Pharmacovigilance Through Utilization of Real World Data"

\title{
1. The Advance of Utilizing Real World Data Under Pharmaceutical Regulatory Schemes Regarding the Approval Review and Post-marketing Safety Assessment
}

\author{
Hideki OI ${ }^{* 1}$, Harumasa NAKAMURA*2 \\ ${ }^{* 1}$ Chief of Development Strategy Office, Translational Medical Center, \\ National Center of Neurology and Psychiatry, Japan \\ ${ }^{*}$ Chief of Clinical Research Support Office, Translational Medical Center, \\ National Center of Neurology and Psychiatry, Japan
}

\section{〈Abstract $\rangle$}

Pharmaceutical regulatory schemes concerned with real world data have been changing remarkably in terms of both drug development and post-marketing.

As for drug development, ICH proposed "GCP Renovation”, which includes modernization of E8 Guideline (General Consideration for Clinical Trials) and subsequent renovation of E6 Guideline (Good Clinical Practice). It covers pragmatic clinical trials, randomized controlled trials using patient registry data, and even observational studies using real world data. In the US, "The 21st Century Cures Act" refers to the proposal concerning speeding up the approval review by making clinical trials more efficient. In fact, there are some cases where real world data was used in the approval review of expanding the application. Also, in Japan, Clinical Innovation Network (CIN) plan was announced, and utilizing the natural history data like patient registry as the control group of clinical trials for the approval review is now under consideration.

As regards post-marketing surveillance, "Conditional \& Accelerated Approval" (October 20, 2017, Yakuseiyakushinhatsu 1020 No. 1) stated that post-marketing confirmation of validity of efficacy and safety using real world data, such as Medical Information Database Network (MID-NET) project and patients registries in CIN plan, is required to get the early approval. Moreover, "The Ordinance on Good PostMarketing Practice" (October 26, 2017, MHLW Ordinance No.116) newly provided "Post-marketing Database Study", which is conducted by use of medical information database like MID-NET, and utilizing real world data for post-marketing safety monitoring began. (Jpn J Pharmacoepidemiol 2019; 24(1):2-10) Keywords: real world data (RWD), GCP Renovation, patient registry, Clinical Innovation Network (CIN), Conditional \& Accelerated Approval 